\title{
Watching Marginal Bodies: Representation of the Transgender Identity on Turkish Media
}

\author{
Assistant Prof. Sertac Timur Demir \\ Department of Radio, Television and Cinema; \\ Communication Faculty, Gümüşhane University, Turkey
}

doi: 10.19044/esj.2017.v13n14p45 URL:http://dx.doi.org/10.19044/esj.2017.v13n14p45

\begin{abstract}
The world in which we live is seen, on the one hand as a global village in some sense and, on the other, as a divided geography. In other words, it is localized and ghettoized simultaneously. The everyday life that transforms rapidly and in an amorphous notion bears testimony to the rise of new identities and belongings as well as new opposition and disengagement. This dilemma generates new and different notion of tension and conflict. Body and gender are considerably significant paradigms in terms of showing and representing this sense of physical, mental and ideological separation; so much so that they change continuously in the shade of freedom and security deadlock. As for media, they do not merely capture but formalized the social events and collective facts. They manipulate the viewer perception and attitudes. From institutional and traditional to individual, digitalized and social media, they redefine the meaning of distant and ambivalent identities and design some clichés about them. That is why this paper is an attempt to describe the representation of marginal identities in Turkish media mainly through television channels, newspapers, internet and films that may stimulate the controversial relationship between normals and deviant and between insider and outsider. For this purpose, in this study, it is focused on the question of how Turkish media display and represent the transvestites.
\end{abstract}

Keywords: Media, Marginality, Transgender Identity, Representation, Turkey, Body and Gender

\section{Introduction}

There is no a certain official statistics on transgender population in Turkey, but according to the Economist (2008), Turkey has more transvestites per head than anywhere bar Brazil. Although the information has not been verified yet, it is possible to claim that transgender identity is one of the crucial problems of Turkey in terms of the European Union 
membership process and more importantly human rights. Turkey is a significant country where is between East and West, Islam and secularism, tradition and modernism. Hence, there are various opposite interpretations and perspectives on the transgender identity in Turkey. Before starting to discuss the marginal identities, it needs to explain what the identity concept is.

First of all, the identity is not only outcome of inclusion in which social synergies are altogether, but also of exclusion that is represented through personal, cultural, geographical and national differences that are indeed abstract concepts and values that are embodied by various specific images and symbols. Although contemporary identities have a tendency to be hybrid (Weeks, 2003: 123), it is possible to claim that indispensability of the difference will remain as crucial as similarities, because the identity is in need of an exclusionary form and an othering mechanism in order to maintain and strengthen itself. In other words, the dominant identity, which may be defined as power which refers Foucault, or authority which reminds Weber, or hegemony which identifies with Gramsci and Althusser, has a necessity of the classification and the labelling.

The elimination process produces continually new marginal individuals that protect their own identities and insist on their marginalities. Weeks claims that these "identities are deeply personal but tell us about multiple social belongings" (ibid: 125), for this reason, according to Mennell (1994: 179), it is difficult to think the "individual self-images" and the "group we-images" as if they are separable parameters. They are as marginal as they deviate from shared, common and acceptable norms. Those who do not share the common norms and who display an attitude against social control are categorized and labelled as extremely different, marginal and deviant (Yurdigul and Yurdigul, 2014: 12) In the documentary film titled 'The Story of A Resistance' (Oztek, 2009), Esmeray who is a transvestite tells a memory that represents the dilemma between Turkish society and transgender identity. In the memory, when Esmeray was a young boy who emulates girls, attempted to join a girlish game: I see a spare needle. I put on the headscarf, fast. I took a needle in my hand. Then I took some yarn... I crossed my legs. Bam! A punch on my head, it's my brother. Another punch, it's my dad. Then my headscarf is gone, it's my mom. I thought: "What did I do now so my father punched me, my brother beat me... My brothers beat my sister every day; my uncles beat their wives every day. So I said, I am a 'girl' that's why they hit me, it's ok.

Individuals who are a part of such social dynamics may start to produce their own identity by creating images and symbols in response to the norms that are enforced by socialization processes such as education, law, religion, customs, etc. This deepens the conflict and the disagreement, 
furthermore, risks of violence and gaps between the sides increase because of the fact that "everybody is the other, and no one is himself" (Heidegger: 1962: 128). The important question is who and how determines the common norms and how to encode them. In this paper, I look for an answer for this question. Moreover, I discuss, first, nature of mass media in the context of Turkish television channels and newspapers and, second, the relationship between the media and marginal identities such as transgender identities.

\section{Methodology}

In this article it is selected 100 news items from these newspapers to analyse representation of the transgender identities. These newspapers were classified into five main groups as populist, liberal, conservative, left-wing and nationalist media in Turkey. Similarly, it is selected some television channels which represent the populist media, the liberal media, the elitist media and the Islamic media. It is watched totally 137 main news bulletins. These are equal to 382 minute and 4 second video. Also, it is analysed Güneşi Gördüm (I Saw the Sun) that is a remarkable film about the conflict between norms and transvestites in Turkey.

\section{The identity of media and the media of identity}

According to Burton (2002), media is crucial and common determining factor to define normal and abnormal behaviours not only in Turkey, but also in other countries which have this kind of identity problems. Mass media is and has a power to manipulate opinions, to reproduce social standards by interacting different groups or identities that are indeed unaware of each other. The interaction involves unexceptionally everybody, even those who do not have any television, radio or internet connection in their homes, because they are affected by others who do have the media. For instance, "many people, probably the vast majority, will never, knowingly, meet a transvestite or a transsexual in their lifetime. But mass communication makes them available to everybody (King, 2002:150). Perhaps that is the reason why the media is such a determining factor in the process of identification. The media, like schools that educate students, reinforces other institutions of hegemony ideologically (Lull, 1995: 33). It provides an artificial answer concerning questions of what is moral, of which identity is acceptable, and of how to be a part of the majority. Media has a power to create majority and mass. People who are represented by media realize that they are not alone and thus they can easily express their ideas based on media, because, as Elisabeth Noelle Neumann in the context of spiral of silence theory, "to the individual, not isolating himself is more important than his own judgment” (1974:43). Mass media, like a religion, preaches 
people about what they need to say and thus, seemingly, save them from being isolated.

One of the important dimensions of this problematic is perception of the audience, because watching and reading activity consist of not only broadcaster that represents encoding process, but also audience that refers decoding process. This means that, broadcasters, sources, producers or encoders are beginning of the mass communication. The second level of the process is applied by audience, receivers and decoders. In addition to these determining factors, there is also a third dimension: message (text). Il $n^{\prime}$ y $a$ pas de hors-texte ${ }^{1}$. Stuart Hall describes the process as "production, circulation, distribution, consumption and reproduction" (Hall, 1980:128). The media produces values to and for societies. It works as if it is a designer that describes social groups which do not meet each other. In other words, media provides a decision making mechanism on behalf of the groups. Thus, the information that is obtained from the media is perceived as sufficient to make a decision on each other. For instance, "many people, probably the vast majority, will never, knowingly, meet a transvestite or a transsexual in their lifetime. But mass communication makes them available to everybody" (King, 2002, 150).

\section{Representation of marginal identities in turkish media}

3.1. Marginal Identity in Tabloids - Populist Media are top on the list of newspapers in terms of total circulation. These newspapers use often street language and slang without hesitation, because people who prefer these newspapers have low level of education as typical feature of tabloids. Transgender identity is represented as a group who either attacks someone or attacked by someone. Thus, the marginal people are increasingly identified with violent behaviour and crimes. There are some newspaper headings ${ }^{2}$ that prove the reality: "Taksimde travesti cinayeti"3 (Habertürk, 2009). "Travestiler döner bıçaklarıyla saldırdılar"4 (Posta, 2010). "Seri cinayet kurbanı HIV'li çıktı"5 (Posta, 04.05.2010). “Travestiler travestiyi protesto etti"6. (Vatan, 2010) According to the newspaper headings, the marginal identities are coded along with aggressiveness, cruelty, contagious disease (AIDS) and incompatibility concepts. Also, Turkish public is sensitive about

\footnotetext{
1 "There is nothing outside the text" (J. Derrida)

2 These newspaper headings, items and reports were translated from Turkish to English. See Appendix for the translation table that contains the original texts.

${ }^{3}$ English translation: "Transvestite murder in Taksim".

${ }^{4}$ English translation: "Transvestites attacked with machetes".

${ }^{5}$ English translation: "It is understood that the victim of serial murder was carrying HIV virus".

${ }^{6}$ English translation: "Transvestites protested the transvestite”.
} 
'terror' and 'violence' term that is often used in the news: "Travestilerin bitmek bilmeyen şiddet eğilimleri", (Star, 2005)

The newspaper cutting may be useful to understand representation of the marginal identities. “Travesti Canan, garson Halil K.'yi döverek hastanelik etti"8 (Sözcü, 2010). In this news report, emphasis is on the adjectives (transvestite and waiter) rather than names (Canan and Halil). According to the news, in subtext, not only Canan, but also every transgender person has a potential to attack an innocent person like a waiter. Turkish media plays role to manage the conflict between normals and marginals or deviants. For instance, Bülent Ersoy, who is a famous transvestite singer in Turkey, is interestingly appreciated even by slum dwellers and those who have strongly potential to kill a transvestite, because Bülent Ersoy is, like a consumption good, affirmed by contrast with other transvestites by the media. Provided that other transvestites are as attractive as Bülent Ersoy, they are able to find a place in the media. Apart from this, violence, blood, fight, sexuality and also undiscovered lives may be attractive for Turkish audience. Ümit Aslanbay, who was once news editor in one of Turkey’s important news channels (NTV), explains the reason of why Turkish media (especially television channels) use the violent items:

"The pressure that compels us to present these kinds of seditious news is to be number one and to have the highest rating proportion. Therefore our duty is to capture every object and events that are on the move, I mean, every attractive images, visual effects, experience and topics have a potential to make us number one. Preferences of audience are shaped within the framework of the attraction of news. We can do everything what we need to do for achieving this aim. There is no another way of being watched by audience” (Aslanbay, 1998 cited in Yurdigul and Yurdigul, 2014: 24).

Liberal or Centre Right Media are second popular with 1.262.000 sales amount. Hürriyet, Milliyet, Sabah, Star, Akşam newspapers and ATV represent liberals in Turkey. Actually, television is more impressive media than newspaper, because it contains both text and repeatable images and additionally sounds. Repetition is one of the influential methods: "Beyoğlu'nda yine kavga ve kavganın içinde yine travestiler"9 (ATV, 2004). In other words, Beyoğlu witnesses a fight again, and actors of the fight are, as usual, transvestites. Thus, an indestructible stereotype (regarding Beyoğlu, transvestites and violence) is created through the news. The stereotype is then generalized and strengthened by using plural forms of the subjects such as transvestite(s). One of the features of the liberal media is to show how

\footnotetext{
${ }^{7}$ English translation: "Endless violent tendencies of transvestites”.

${ }^{8}$ English translation: "Transvestite Canan beat the waiter Halil K. up”.

${ }^{9}$ English translation: Fight once again in Beyoglu and once again transvestites in the fight"
} 
transgenders are punished: "Travestilere 116 y1l hapis"10 (Star, 2010). This involves an implicit warnings, namely it emphasizes that public is under threat because of the transvestites.

\section{Conservative Media}

It is necessary to focus on Islamic perspective on the marginal identities in order to explain the conservative media's approach. When it is considered that Turkish society is composed of over 99\% Muslim population, it can be easily understood that the Islamic perspective is dominant in Turkey; therefore the Islamic perspective is important to understand the Turkish society as well. In Islamic doctrine, Allah (God) made two sexes, male and female ${ }^{11}$. The two genders represent natural and normal identities. Transsexualism is therefore considered a sin (Slamah, 1998: 213). According to Islam, one is born a woman, but not becomes one in contradistinction to Beauvoir (1973: 301). Only, the marginal identities such as transgenders and homosexuals are not natural given ${ }^{12}$ and constructed $^{13}$. Generally, the conflict between the marginal identities and Islam arises from different interpretations regarding becoming and being. For instance, in Turkey, male-to-female transsexuals who died are buried according to Islamic procedures and the transsexual is accepted as a man in the context of the procedures. Moreover, in the Islamic perspective, it is impossible to claim that homosexuality is genetic. Instead of that, reasons that reveal the marginal identities are mainly cultural. It can be accepted that some people may be prone to homosexuality, however all people already tend to sin. The human task, in the sight of Islam, is to struggle against the perversion as a learned and an amendable behaviour. News, in the conservative media, is mainly about the conflict between society and marginal lives in order to illustrate that the marginals are out of the Turkish society: "Fight between society and transvestite” (Türkiye, 2001). In addition, the media interest in transgenders in the context of AIDS.

\section{Left Wing Media}

They are comparatively more qualified and autonomous, as a consequence of that, these newspapers reach only 150.000 people a day. Media provide opportunity to show existence of the marginal identities (Rooke, 2010: 75); nonetheless appearing in media is too difficult for them, unless they die. Left media tend to protect transgender against discrimination problem in Turkish society and the media mainly criticize some official

\footnotetext{
${ }^{10}$ English translation: “Transvestites were sentenced to 116 years

${ }^{11}$ This is a verse of Quran; Al-Qiyámah/39 (The Resurrection/39)

${ }^{12}$ The term is borrowed from Foucault (1978: 152)

${ }^{13}$ The term is borrowed from Butler (2006: 11)
} 
groups that commit violence like police forces. One of the most visible features of left wing media is to use ironic language: "Hurray, I am still alive today (Radikal, 2009). As a dimension of the ironic language, left media also use some metaphors to criticize the social pressure and other media groups: "Yaşasın bugün de hayattayım"14 (Gündem, 2004). Cleanliness concept is an interesting representation, because, first of all, it means that transgenders are dirty. In other words, someone needs to clean them up. Secondly, cleanliness refers eradication. As it seen, representation, as a media language, reproduces meanings of value or identity.

\section{Nationalist Media}

Nationalist media in Turkey are based on ideology and politics; therefore, whenever the media attempt to criticize problematic of the marginal identity, they criticize governments. This means that, transsexualism is predominantly evaluated as a political rather than social and cultural phenomenon. Cumhuriyet, in comparison with other newspapers, which is close to secularism supports the transgender identity and defines them as a "colour of rainbow" (Cumhuriyet, 2009), whereas Yeniçag, is traditional nationalist newspaper, uses very sharp language. For instance, Altemur Kılıç, a columnist preferred the word "the night monsters" phrase to define Bulent Ersoy (Yeniçag, 2008).

\section{Film as Media}

Film is a space of freedom for the marginal identities. They can express their identities by means of the independent camera. Films in Turkey are more courageous than other media like television, radio and newspapers, so those who want to understand the reality of the transgender should watch films that are produced in Turkey. Güneşi Gördüm is one of them and it is crucial to comprehend the conflict between transgenders and customs. It is possible to see marginal identities (immigrants, minorities, poor, women in countryside, prostitutes, transsexuals etc) of Turkey through the movie: Güneşi Gördüm, 2009). This is the story of a Kurdish family that immigrated to Istanbul and Finland from East of Turkey. Kadri, or Kado as his elder brother calls or Kezban as transgenders call ${ }^{15}$, is one of the supporting actors.

According to the story, Kadri, in a patriarchal family, represents those who are between being men and becoming women. He believes that he has a

\footnotetext{
${ }^{14}$ English translation: “A cleaning campaign against transvestites”

${ }^{15}$ Kado is emphatically masculine saying of Kadri, whereas Kezban is a woman name. Kado and Kezban names represent, in this context, conflict between Kadri's elder brother belief (customs) and transvestite culture (marginality).
} 
man's body, but feminine feelings, namely he is different from other men. Eventually, Istanbul gives a chance to him in terms of self-disclosure. Kadri meets other transvestites and he is no longer Kado or Kadri, but Kezban. Nevertheless his elder brother who represents patriarchal perspective does not accept this situation. As he says: "there is no place for pansies in our family!" Hence, Kezban understands that his family will kill him: It's customary to migrate but this isn't about customs. My brothers can't bear me being like this. They won't rest easy until they have killed me”. Kezban is right, his elder brother kills him, but then he regrets. At the end of the film, the director adds this comment: It's us men who want war and the mothers who weep. It's my belief that only mothers can put an end to this business.

\section{Debates and findings}

In Turkey, resistance of media readers is limited, because the media is evaluated by the readers as an incontrovertible authority in parallel with level of education. There are various factors that determine decoding process of message (text or image) such as custom, law, army, religion, neighbourhood, family structures, social relationships and even geography and climate. These determining factors are very strong in Turkey in comparison with other European countries. For instance, Turkish military is considered as semisacred politically, traditionally and historically. The powerful military means powerful male-dominated society, because military is, as Kronsell (2005:281) states, one of the hegemonic and masculine institutions. Turkish media generally have interpreted this statement as if it is a political or an ideological issue. Some media groups which do not support AKP government have excoriated the statement, whereas other media groups which have close relationships with the government have supported this approach. In fact, this controversial problem has been discussed very thoroughly, but by limited elitist newspapers and television channels and therefore accessible to the few people who already hold an opposing view on the violence trend that is instigated by some Turkish media groups.

Generally, transgender identity, as a condemned social group (Slamah, 1998: 212); is very intriguing topic for Turkish media, because it contains almost everything that Turkish society needs ${ }^{16}$ to read and watch. Despite the fact that Turkish people have said that they have complained about the violence in the newspaper and the television news (Sahin, 1998), it is appeared that especially news bulletins which involve violent images or language have ironically high level of rating. There are some concepts that are frequently used in Turkish media to create artificial representation about the transgender identity. These concepts are attack, disease, insanity,

\footnotetext{
${ }^{16}$ These are artificial needs that are based on weaknesses of human being.
} 
prostitution, sex workers, HIV/AIDS, sin, rape, death, rape, terror, gang, freedom, legal rights, NGO (Non-governmental organization) and protestation. These concepts can be gathered under the six titles like below:

\section{Representation of Transgender I dentity in Turkish Media}

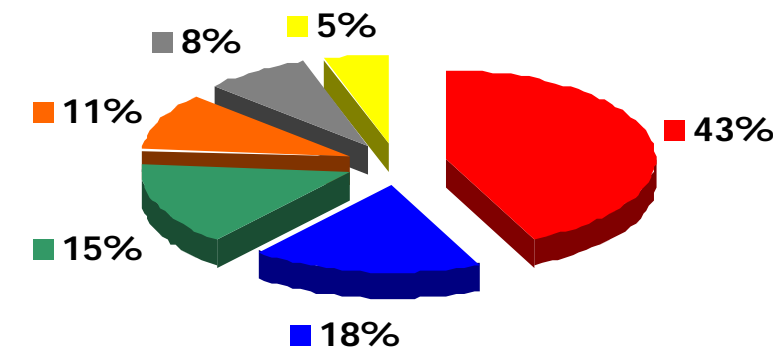

\begin{tabular}{|l|}
\hline Violence \\
- Disease \\
neligion \\
n Freedom \\
Protestation \\
Prostitution \\
\hline
\end{tabular}

It is observed that $43 \%$ of news items contain messages on violence that transgenders caused. 18 news reports are about whether transvestism and transsexualism are disease or not. This kind of news also emphasizes HIV/AIDS. The third most common approach that criticizes the transgender identity consists of religious perspective with 15 news items. Despite of the fact that there has generally been a certain difference between religious and secular media in Turkey, there has been a surprising similarity between the ideological poles regarding transgender identity.

Transgenders give interviews in 17 news reports, while some experts such as psychologists, sociologists and surgeons share their opinions on the marginal in 7 news reports. These interviews are nevertheless edited in line with the perspective of the news. In other words, they give themselves up. It was encountered that 31 of 56 television news reports were designed with simplified texts and repeated images. Moreover, in the television channels, names are deliberately used with their plural forms in order to generalize the marginal identities. Impressions of the transgender identity that are reflected from Turkish media are unhappy, neurotic, obsessive, loveless, sick, alone and maladjusted.

Texts of the news reports may be exhausting for the standard audience, therefore editors prefer very simple language to be understood and secondly they strengthen the texts by using remarkable images and visuals. Transvestites, in the news, are imaged with red stockings, high heeled and 
large sized shoes and heavy make-up (Yurdigul and Yurdigul, 2014: 23). The visuals are emphasized with long-plays and circles and are reinforced through repetitions. Media deliberately focuses on physical appearances and clothing of the marginals in order to separate them from normals, because clothing, as Marjorie (1992: 3) mentioned, has a great power to construct and deconstruct gender.

However, in Turkey, the constructability level of clothing has been declining as consequence of new fashion culture that has an undeniable potential. It deeply shakes the power of heterosexuality. Make-up, for instance, is not peculiar to women. More obviously, distinctive features of genders tend to disappear. New generation men and women are no longer similar to each other as clothing and physical appearance. They unify their gender differences under the name of metro-sexuality. The newfangled but artificial identity familiarizes and integrates the old but real transgender identity into society that is managed by rule-makers. Nevertheless hegemonic masculinity, according to Whitehead (2002: 89) is still dominant and it continues to use force on people about how to be real men.

There is no doubt that the end purpose of media is to create public opinion and majority that are motivated against marginal identities. Turkish media therefore prefer news that includes blood, aggression, conflict and friction etc. In other words, media are nurtured by dialectic between opposite perspectives. In the "Transvestite Terror" documentary film (Atasay, 2005), journalist Tuğrul Eryılmaz reported that the identity which is the most horribly represented in Turkish media is transgender identity. More importantly, this marginal identity is a cultural symbol, and the symbol represents how media turn 'intimacy' into 'public' through the news. Events are inherently neutral, but representation refers a subjective activity. In other words, events are not able to make a sense without the media manipulation as Hall (1999: 236) mentioned, furthermore, they are encoded in a different form in order to provide a social understandability through the representation. Shortly, nothing is what it seems in the world of media.

\section{Conclusion}

The representation styles of the marginal identities are important for those who learn the social events by means of media rather than by observing or experiencing. It is possible to claim that there is a visible and a strong similarity between language of the news reports and the audience opinions on transgender identity. In other words, media has been playing role to create violence against the marginals. People who do not communicate with transgenders have, nevertheless, certain ideas or stereotypes about the marginals. 
Media shapes public opinion against transgender identity by showing their differences rather than similarities each other. After that, "the concept of difference creates a tremendous dilemma” (Shildrick, 1997:108). If looked at some other researches on the dilemma between public and marginal identities in the context of violence, it is appeared that media is one of the most influential determining factors. More obviously, Turkish media has a strong function to create violence against transgenders, so it is difficult to have a strong identity for the marginal groups, because there is a stronger power that they have to struggle and “comes from everywhere” (Foucault 1990:93).

As mentioned before, there has been a visible dilemma between sides in Turkey. Although change of sex is legal since 1973, it is very difficult to show any structure to support transsexuals (Whittle, 2002:276). According to a research that is conducted by the CISED $^{17}$ in $2005,75 \%$ of heterosexuals and $40 \%$ of homosexuals evaluated homosexuality as a sexual perversion and $55 \%$ of heterosexuals and $35 \%$ of homosexuals believe homosexuality can be treated. Homosexuality is a conscious choice in the eyes of $40 \%$ of heterosexuals and $60 \%$ of homosexuals.75\% of heterosexual participants is against the homosexuality and they would end their friendship with a friend who turns out to be gay and $95 \%$ of them said homosexuals should never be granted the right of marriage. All heterosexuals and 95\% of homosexuals did not want their children to be gay (Hurriyet Daily News, 2009). Why did not the homosexuals their children to be gay? Is there any relationship between being marginal and violence?

Lambdaistanbul $\mathrm{LGBTT}^{18}$ conducted a research ${ }^{19}$, called 'you are neither wrong nor alone', on the violence problem in 2005. 87\% of homosexuals and bisexuals exposed to at least one of social violence forms. $23 \%$ of them exposed physical violence. $9 \%$ of participants mentioned that they experienced verbal abuse at least once, but 65\% of them experienced it more than once. Additionally, according to Human Rights Watch Reports (2008), in Turkey, 89\% transvestites and transsexuals exposed to physical violence and $52 \%$ of them exposed to sexual violence. This means that, the power, by contrast with Foucault (2000: 19), punishes bodies rather than souls in Turkey. This punishment style is a nature of collectivist societies, because this kind of punishment is a sort of show to exhibit abnormal identities and to settle up with them on behalf of norms and normals. It is strongly possible to state that spiritual punishment refers individual societies,

\footnotetext{
${ }^{17}$ Sexual Health Institution Society

18 Lambdaistanbul Lesbian, Gay, Bisexual, Transvestite, Transsexual Association.

19 It is possible to see detailed results of the research on: www.lambdaistanbul.org/s/
} 
but bodily punishment is still a key point of the revenge. Namely, in last five years, more than twenty transvestites tragically killed in Turkey.

For this reason, the marginal identities, from transsexuals to homosexuals, held a meeting in Istanbul (Guzistanbul Turkiye, 2002) in order to share their expectations and look for a solution on the representation problem in Turkish media. These expectations show similarity with interviews that they gave on television programs, newspapers and also internet forums before. Accordingly, the marginal identities are uncomfortable with the idea that they are merely sex workers and social monsters. They believe that the stereotype is created by media. They do not want to be used as a newsworthy item, instead, they want to state their real identities without representation and speculative news. They do not want to conflict with society, so they are unambiguously against the news language that provokes violence. Finally, beyond these expectations, they wish to live a normal life that is protected by the laws and social agreement.

\section{References:}

1. 'Homosexuality is a Disease' says Turkish Minister (2010) Hurriyet Daily News 07.03.2010 http://www.hurriyetdailynews.com/n.php?n=8216 homosexuality-isa-disease8217-says-minister-2010-03-07

2. A Cleaning Campaign against Transvestites (2004) Ozgur Gundem, 09.10.2004

3. Akyol, Esmahan (2009) Radikal 25.10.2009 'Hurray, I am still alive today' http://www.radikal.com.tr/Radikal.aspx?aType=RadikalEklerDetay\& ArticleID $=960799 \&$ Date $=25.10 .2009 \&$ CategoryID $=42$

4. Aslanbay, Ümit (1998) “Television Broadcasting of News”, III. National Media Seminar Speech. Bursa. http://www.byegm.gov.tr/seminerler/bursa-iii/burkonusma10.htm (Accessed 29 December 2010)

5. Beauvoir, S. (1973) The Second Sex, New York: Vintage.

6. Burton, G. (2002) More Than Meets the Eye: An Introduction to Media Studies,More Than Meets the Eye:An Introduction to Media Studies, London: Arnold; New York: Oxford University Press.

7. Butler, Judith (2006) Gender Trouble: Feminism and the Subversion of Identity, New York: London: Routledge.

8. Colours of Rainbow (2009) Cumhuriyet, http://www.cumhuriyet.com.tr/?im=yhs\&hn=65198

9. Fight between Society and Transvestite (2001) Turkiye, http://www.turkiyegazetesi.com/haberdetay.aspx?haberid=117065

10. Foucault, M (1990) The History of Sexuality: The Will to Knowledge, 
Trans. by R. Hurley, Penguin Books.

11. Foucault, M. (1978) The History of Sexuality, Volume 1: An Introduction, Harmondsworth: Penguin.

12. Foucault, M. (1979) Discipline and Punish: The Birth of the Prison, New York: Random.

13. Garber, M. B. (1993) Vested Interests: Cross-Dressing and Cultural Anxiety, London: Routledge.

14. Gays Unhappy with Lifestyle Choice, Shows Study - CISED Research (2009) Hurriyet Daily News /n.php?n=gays-unhappy-withlifestyle-choice-reveals-research-2009-07-08http://www.hurriyet daily news.com/n.php?n=gays-unhappy-with-lifestyle-choice-revealsresearch-2009-07-08

15. Guzistanbul Turkiye (2002) 'What Do Homosexuals Want' Istanbul. morel.eskisehir.googlepages.com/E.NeIstiyor.pdf

16. Hall, S. (1980) 'Encoding/decoding' in Centre for Contemporary Cultural Studies', Culture, Media, Language: Working Papers in Cultural Studies, 1972-79 London: Hutchinson.

17. Heidegger, M (1962) Being and Time, Translated by J. Macquarrie and E Robinson, Oxford: Basil Blackwell.

18. Human Rights Watch (2008) 'Gender Mainstreaming, Sexism and Human Right in Turkey", http://panel.stgm.org.tr/vera/app/var/files/t/u/turkey0508tuweb.pdfhtt p://panel.stgm.org.tr/vera/app/var/files/t/u/turkey0508tuweb.pdf

19. It is Understood that the Victim of Serial Murder was Carrying HIV $\begin{array}{lll}\text { Virus (2010) Posta } & \text { 04.05.2010 }\end{array}$ http://www.posta.com.tr/turkiye/HaberDetay/

Seri_cinayet_kurbani_HIV_li_cikti.htm?ArticleID=28645\&Date=22. 04.2010

20. Kilic, A. (2008) Night Women, Night Monsters” Yenicag, http://www.yg.yenicaggazetesi.com.tr/yazargoster.php?haber=2763

21. King, Dave. (2002) 'Cross-Dressing, Sex-Changing and the Press' in R. Ekins and D. King eds., Blending Genders: Social Aspects of Cross-Dressing and Sex-Changing, London: New York : Routledge.

22. Kronsell, A. (2005) 'Gendered Practices in Institutions of Hegemonic Masculinity’, International Feminist Journal of Politics 7(2): 281.

23. Lambdaistanbul LGBTT Association (2005) 'You are Neither Wrong nor Alone: A Case Study of Homosexuals and Bisexuals Problems', Istanbul.

24. Lull, J. (1995) Media, Communication, Culture A Global Approach, Cambridge Polity Press.

25. Mennell, S. (1994) 'The Formation of We-Images: A Process Theory' 
in C. Calhoun ed., Social Theory and The Politics of Identity, London: Blackwell.

26. Murder of Transvestite (2009) Haberturk http://www.haberturk.com/yasam/haber/133648-taksimde-travesticinayeti

27. Noelle-Neumann, E. (1974) 'The Spiral of Silence A Theory of Public Opinion', Journal of Communication 24 (2): 43.

28. Rooke, A (2010) 'Telling Trans Stories (Un)doing the Science of Sex' in S. Hines and T. Sanger eds., Transgender identities: towards a social analysis of gender diversity, New York: Routledge.

29. Sahin, Haluk (1998) 'Where Do the Journalistic Ethics and Reporting Go', III. National Media Seminar Speech. http://www.byegm.gov.tr/seminerler/bursa-iii/burkonusma6.htm

30. Shildrick, M (1997) Leaky Bodies and Boundaries: Feminism, Postmodernism and (Bio)ethics, London: New York : Routledge.

31. Slamah, Khartini. (1998) 'Transgenders and Sex World in Malaysia' in K. Kempadoo and J. Doezema eds., Global Sex Workers: Rights, Resistance, and Redefinition, New York: Routledge.

32. The Transvestite was protested by other Transvestites (2010) Vatan, http://haber.gazetevatan.com/travestiler-travestiyi-protestoetti/342728/7/ Yasam

33. Transvestites Attacked With Machetes (2010) Posta, http://www.posta.com.tr/turkiye/HaberDetay/Travestiler_doner_bicak lariyla_saldirdi.htm?ArticleID=31259

34. Transvestites in Turkey (2008) The Economist, http://www.economist.com/node/12564128?story_id=12564128

35. Transvestites were Sentenced to 116 Years (2010) Star, http://www.stargazete.com/guncel/travestilere-116-yil-hapis-cezasihaber-257839.htm

36. Yurdigul, Y., and Yurdigul, A. (2014) Presentation of the Marginal Identity on Television News (The Turkey Example), Atatürk Üniversitesi Sosyal Bilimler Enstitüsü Dergisi, 18 (2): 11-30.

37. Weeks, J. (2003) 'Necessary Fictions: Sexual Identities and the Politics of Diversity' in J. Weeks, J. Holland and M. Waites eds., Sexualities and Society, Cambridge: Polity Press.

38. Whitehead, M. S. (2002) Men and Masculinities, Oxford: Blackwell Publishers.

39. Whittle, S. (2002) Respect and Equality: Transsexual and Transgender Rights, London: Cavendish. 